\title{
Rola mózgowego czynnika neurotroficznego (BDNF) w procesach neurodegeneracji oraz $w$ mechanizmach neuroregeneracji wywołanej wzmożoną aktywnością fizyczną
}

\section{Paulina Małczyńska ${ }^{1, \#}$}

\section{Zofia Piotrowicz ${ }^{2, \#}$}

\section{Dorota Drabarek ${ }^{3}$}

\section{Józef Langfort ${ }^{4}$}

\section{Małgorzata Chalimoniuk ${ }^{3, 区}$}

${ }^{1}$ Zakład Genetyki, Instytut Psychiatrii i Neurologii, Warszawa

${ }^{2}$ Katedra Teorii i Praktyki Sportu, Wydział Wychowania Fizycznego, Akademia Wychowania Fizycznego im. J. Kukuczki w Katowicach ${ }^{3}$ Wydział Turystyki i Zdrowia, Akademia Wychowania Fizycznego Józefa Piłsudskiego w Warszawie, Fila Biała Podlaska ${ }^{4}$ Zakład Farmakologii Doświadczalnej, Instytut Medycyny Doświadczalnej i Klinicznej im. M. Mossakowskiego PAN, Warszawa

$\triangle$ Wydział Turystyki i Zdrowia, Akademia Wychowania Fizycznego Józefa Piłsudskiego w Warszawie Fila Biała Podlaska, ul. Akademicka 2, 21-500 Biała Podlaska; tel.: 798 058 800, e-mail: malgorzata.chalimoniuk@awfbp.edu.pl

\#równy wkład pracy w przygotowanie manuskryptu

Artykuł otrzymano 26 lipca 2018 r.

Artykuł zaakceptowano 13 grudnia 2018 r.

https://doi.org/10.18388/pb.2019_251

Słowa kluczowe: mózgowy czynnik neurotroficzny, neurodegeneracja, neuroregeneracja, wysiłek fizyczny, proces treningowy

Wykaz skrótów: AkT - kinaza białkowa B; BDNF (ang. brain-derived neurotrophic factor) mózgowy czynnik neurotroficzny; CaMK II kinaza białkowa zależna od wapnia i kalmoduliny II; CREB (ang. cyclic-AMP response element-binding) - czynnik transkrypcyjny aktywowany w odpowiedzi na cAMP; HIIT - interwałowy wytrzymałościowy trening o dużej intensywności; miRNA - mikroRNA; NT - neurotofiny; p75NTR - receptor p75NTR należący do rodziny receptorów czynnika martwicy nowotworu; PD - choroba Parkinsona; TH - hydroksylaza tyrozynowa, Trk - receptory $\mathrm{z}$ rodziny receptorów kinazy tyrozynowej $\mathrm{A}, \mathrm{B}, \mathrm{C}$

Podziękowanie: Praca powstała w trakcie realizacji projektu badawczego finansowanego przez NCN nr 2017/25/B/NZ7/02795 i projektu AWF J. Piłsudskiego w Warszawie nr DS.253.

\section{STRESZCZENIE}

Tózgowy czynnik neurotroficzny (BDNF) należy do rodziny neurotrofin syntetyzowanych w komórkach ośrodkowego oraz obwodowego systemu nerwowego. $W$ regulacji syntezy białka BDNF uczestniczy kilka specyficznych miRNA (miR-1, miR-126 i miR-30a5p). Na jego syntezę może mieć wpływ polimorfizm SNP - Val 66Met BDNF (rs6265). BNDF może swobodnie przekraczać barierę krew mózg. Jego efekt centralny i obwodowy polega na regulacji istotnych funkcji fizjologicznych i patologicznych organizmu: rozwój i wzrost neuronów, procesy uczenia się i pamięci, apoptozy, neurogenezy oraz neuroregeneracji poprzez aktywację receptorów TrkB i p75NTR. Obniżenie poziomu BDNF pośredniczy w neurodegeneracji neuronów $w$ tym neuronów dopaminergicznych $i$ jest obserwowane $w$ chorobie Parkinsona. Regularnie powtarzany długotrwały wysiłek fizyczny lub proces treningowy o średniej lub dużej intensywności wywołuje wzrost poziomu BDNF i receptora TrkB w regionach mózgu odpowiedzialnych za aktywność motoryczną, zapobiegając procesom neurodegeneracji, szczególnie u osób starszych.

\section{WPROWADZENIE}

Choroby neurodegeneracyjne są jednym z najczęstszych schorzeń ośrodkowego układu nerwowego (OUN) i charakteryzują się wieloczynnikową patogenezą. Procesy neurodegeneracji w OUN są odpowiedzialne za powstawanie zaburzeń ruchowych, mentalnych, uczenia się i pamięci oraz deficytów kognitywnych u pacjentów z chorobą Parkinsona (PD), Alzheimera (AD) czy stwardnieniem rozsianym (SM). Istnieje coraz więcej danych wskazujących, że jedną z przyczyn neurodegeneracji neuronów może być obniżenie poziomu czynników neurotroficznych, w tym mózgowego czynnika neurotroficznego (BDNF) w mózgu i surowicy oraz związany z tym zjawiskiem brak aktywacji szlaku sygnałowego IP3K/Akt (prożyciowego), co z kolei aktywuje proces apoptozy. Obecnie poszukuje się sposobu na wyrównanie deficytu BDNF przez bezpośrednie podawanie BDNF w miejscu uszkodzenia neuronów lub wszczepianie do tych struktur mózgowych materiałów stopniowo uwalniających tę neurotrofinę. Uzyskane wyniki są wciąż we wstępnej fazie badań ale wskazują na poprawę i przyspieszenie procesu regeneracji neuronów. Alternatywnym nieinwazyjnym sposobem, który mógłby wyrównać deficyt w stężeniu BDNF jest zastosowanie czynników środowiskowych/fizjologicznych, które stymulują jego produkcję. Dosyć dobrze rozpoznanym czynnikiem fizjologicznym, który może podnieść poziom BDNF w OUN i we krwi jest wzmożona aktywność fizyczna. Opierając się na dostępnych w publikacjach wynikach badań, w niniejszej pracy podjęto próbę wskazania współudział BDNF w procesach neurodegeneracji oraz w mechanizmach neuroregeneracji wywołanych wzmożoną aktywnością fizyczną.

\section{MÓZGOWY CZYNNIK NEUROTROFICZNY (BDNF) - REGULACJA SYNTEZY}

Mózgowy czynnik neurotroficzny (BDNF, ang. brain-derived neurotrophic factor) należy do rodziny neurotrofin, polipeptydowych czynników wzrostu, które zostały odkryte w ciągu ostatnich 50 lat [1-3]. Do rodziny neurotrofin (NT) oprócz BDNF zalicza się neurotrofinę 3 (NT-3), neurotrofinę 4 (NT-4), neurotrofinę 7 (NT-7) i glejowy czynnik neurotroficzny (GDNF), które są produkowane w mózgu i innych tkankach [1,3-5]. Badania wykazały, że neurotrofiny mają szereg cech wspólnych, tj. podobną masę cząsteczkową (13.2-15.9 kDa), punkt izoelektryczny (zakres 9-10) oraz 50\% sekwencji reszt aminokwasowych cząsteczki białka [6]. W roztworach występują w postaci niekowalencyjnie związanych dimerów. Białka wszystkich neurotrofin są syntetyzowane w identyczny sposób [6,7].

Gen bdnf zlokalizowany jest na chromosomie 11, reguluje syntezę BDNF i składa się z 9 promotorów inicjujących powstanie 24 transkryptów mRNA [8], posiadających na końcu 5' ekson, który wraz z końcem 3' tworzy otwartą ramkę 
odczytu dla BDNF [9]. Dzięki wykorzystaniu alternatywnych promotorów, splicingu oraz miejsca poliadenylacji może powstawać 24 różnych transkryptów, które kodują identyczne białko BDNF. Proces transkrypcji związany ze wszystkimi 24 transkryptami nie jest dokładnie znany. Jedna z hipotez dotycząca tego procesu zakłada, że użycie różnych promotorów daje zróżnicowane transkrypty, które po obróbce potranslacyjnej w ostatecznym etapie dają to samo białko [6]. W wyniku translacji z mRNA nuerotrofin pierwsze syntetyzowane jest białko o masie cząsteczkowej $32 \mathrm{kDa}$ zwane proneurotrofiną, a w przypadku BDNF, proBDNF. Pro-neurotrofiny, $\mathrm{w}$ tym pro-BDNF, podawane są modyfikacji post-translacyjnej N-glikozylacji w aparacie Golgiego (ang. trans-Golgi network), które następnie jest uwalniane do cytosolu [6]. Proces N-glikozylacji jest bardzo istotnym procesem $\mathrm{w}$ powstaniu neurotrofin. Wykazano, że zablokowanie tego procesu powoduje hamowanie uwalniania proBDNF do cytosolu i $\mathrm{w}$ konsekwencji zmniejszenie poziomu tej proneurotrofiny $\mathrm{w}$ komórce [6]. Następnie $\mathrm{w}$ cytosolu proBDNF jak również inne proneurotrofiny ulega proteolizie $[6,10,11]$ z N-końca białka prekursorowego przy udziale proteaz (plazmina, metyloproteaza 9) odcinany jest dojrzały BDNF (mBDNF, ang. mature BDNF) o masie cząsteczkowej 14 kDa [6]. Badania wykazały, że z N-końca proBDNF $\mathrm{w}$ innym mechanizmie niż mBDNF może być również uwalniany dłuższy odcinek o masie cząsteczkowej 28 kDa zwany kadłubowym BDNF (tBDNF, ang. truncated $B D N F)$. Co więcej, eksperymenty z wprowadzeniem mutacji $\mathrm{w}$ miejscu proteolitycznego cięcia przez proteazy, $\mathrm{W}$ wyniku którego odłączany jest tBDNF, wykazały, że uwalnianie $\mathrm{tBDNF}$ nie jest potrzebne do powstawania m-BDNF [6]. W cytosolu neuronów hodowli pierwotnej i medium stwierdzono obecność 3 form BDNF: proBDNF, mBDNF i tBDNF [6]. ProBDNF i mBDNF mają podobne działanie fizjologiczne, natomiast nadal niewiele wiadomo, jaką funkcję fizjologiczną pełni t-BDNF.

Badania z ostatnich lat dostarczyły dowodów, że w regulacji syntezy białka neurotrofin uczestniczy kilka specyficznych małych niekodujących cząsteczek RNA zwanych mikroRNA (miRNA), tj. miR-1, miR-126 czy miR-30a-5p [12]. Wiadomo, że miRNA uczestniczą $\mathrm{w}$ regulacji syntezy białka poprzez przyłączenie się do mRNA wyciszając jego transkrypcję [13]. Stwierdzono, że zaburzenie fizjologicznego poziomu miR-1 i miR-30a-5p korelowało z zaburzeniem poziomu BDNF w surowicy u pacjentów z chorobą Parkinsona (PD) $[12,14]$. Na poziom tkankowego i krążącego we krwi BDNF ma również wpływ polimorfizm jego genu. Istnieją dane wskazujące, że skojarzone z polimorfizmem SNP Val66Met BDNF (rs 6265), w którym następuje zamiana reszty Val na Met $\mathrm{w}$ pozycji 66 jest występowanie niższego poziomu BDNF w surowicy [15]. Wiadomo, że występowanie Val w pozycji 66 cząsteczki mRNA BDNF powoduje nieprzyłączanie się miR-30a-5p do tej sekwencji, przez co dochodzi do aktywacji procesu translacji i w konsekwencji powstania białka BDNF. Natomiast zamiana reszty Val na Met w pozycji 66 (czyli genotypu AA lub AG) pozwala na przyłączenie się miR-30a-5p, co prowadzi do obniżenia syntezy BDNF [13]. Badania ostatnich lat dostarczyły pierwszych dowodów, że posiadanie polimorfizmu Val66Met BDNF (rs 6265) może zwiększać ryzyko występowania PD lub schizofrenii $[16,17]$.

\section{DZIAŁANIE NEUROTROFIN POPRZEZ AKTYWACJĘ SPECYFICZNYCH RECEPTORÓW}

Zarówno proBDNF jak i BDNF posiadają biologiczną aktywność [6], jednak BDNF i inne neurotrofiny są 10-20 krotnie bardziej aktywne biologiczne niż ich formy pro [18]. Wykazano, że neurotrofiny mogą działać autokrynie, parakrynie i endokrynnie poprzez przyłączanie się do swoistych receptorów zlokalizowanych w błonie komórkowej lub w jądrze komórkowym [19]. Swoje działanie wywierają poprzez regulowanie wielu procesów, między innymi: rozwoju neuronów i ich fizjologicznych funkcji, stymulacji połączeń dendrytycznych, neurogenezy oraz hamowania procesu apoptozy [19].

BDNF jak i inne neurotrofiny wiążą się do specyficznych receptorów z rodziny receptorów kinazy tyrozynowej (Trk) A, B, C i do receptora p75NTR należącego do rodziny receptorów czynnika martwicy nowotworu (ang. tumor necrosis factor receptor family), wykazując różne powinowactwo do poszczególnych receptorów [20-23]. BDNF wiąże się do receptora TrkB i p75NTR, natomiast nie wiąże się do receptorów TrkA i TrkC [ 20]. Ponadto, BDNF wykazuje większe powinowactwo do receptora TrkB niż proBDNF [20]. BDNF i proBDNF wiążą się do zewnątrzkomórkowej domeny receptora TrkB tą samą sekwencją reszt aminokwasowych. Sekwencja pierwszych 54 reszt aminokwasowych N-końca występująca $\mathrm{w}$ proBDNF jak i w proNGF nie jest potrzebna do aktywacji receptora TrkB [20,23]. W porównaniu z BDNF, proBDNF wykazuje większe powinowactwo do receptora p75NTR, którego stymulacja powoduje aktywację procesów neurodegeneracyjnych $[23,24]$. BDNF może wywoływać przeciwstawne działania w zależności czy wiąże się z receptorem TrkB czy p75NTR. I tak, aktywacja receptora TrkB wywołuje protekcyjny efekt antyapoptotyczny, natomiast aktywacja receptora p75NTR powoduje aktywacje procesu apoptozy [8]. Wiązanie BDNF lub proBDNF do receptora TrkB powoduje autofosforylację receptora na reszcie Tyr 490 i aktywację szlaku związanego z kinazą ERK1/2, białkiem Ras i IP3 kinazą (PI3K) $[20,25]$. Ponadto wykazano, że aktywacja receptora TrkB przez BDNF może uczestniczyć w aktywacji szlaków sygnałowych z udziałem MAP kinazy, PI3K, PLC $\gamma$, CaMK II i Ras/ERK [25,26], a także w przyłączeniu białek G, Rap1, catch7, Roc-Pho do fosfolipazy C, powodując jej aktywację oraz uwalniania inozytolu trifosforanu $\left(\mathrm{IP}_{3}\right)$ i diacyloglicerolu (DAG) z fosfolipidów błony komórkowej [27]. Wzrost stężenia DAG powoduje aktywację kinazy białkowej C, która wywołuje fosforylację ERK1/2 kinazy oraz aktywację szlaku związanego $\mathrm{z}$ tą kinazą [25]. Uwalnianie $\mathrm{IP}_{3}$ powoduje aktywacje receptora $\mathrm{IP}_{3} \mathrm{w}$ siateczce śródplazmatycznej (ER) i wzrost uwalniania jonów wapnia do cytosolu. Wzrost stężenia BDNF powoduje także wzrost fosforylacji Akt kinazy na reszcie Thr 308 i aktywację szlaku PI3 kinazy (szlaku antyapoptotycznych) związanego z kontrolą procesu apoptozy poprzez fosforylacje proapoptotycznego białka BAD i w konsekwencji inaktywację kaspazy 9 oraz GSK-3beta [25]. Wiadomo, że fosforylacja na Thr 308 Akt kinazy jest kluczowa dla aktywacji neuroprotekcyjnego szlaku sygnałowego IP3K [25]. Dotychczas nie określono czy fosforylacja Akt Ser $473 \mathrm{w}$ odpowiedzi na działanie neurotrofiny jest związana z procesami neuroprotekcyjnymi [28], natomiast wiadomo, 
że Akt kinaza fosforyluje GSK-3beta na reszcie Ser 208, co prowadzi do jej inaktywacji i hamowania proapoptotycznego działania tej kinazy [27]. Nieufosforylowana GSK-3beta jest aktywna i odgrywa istotną rolę w procesie apoptozy poprzez fosforylację licznych swoich substratów, np. białka tau [27]. Wzrost aktywacji GSK-3beta obserwowano w chorobach neurodegeneracyjnych: chorobie Alzheimera (AD) i PD [27]. Obniżenie poziomu BDNF w chorobach neurodegeneracyjnych może być przyczyną aktywacji GSK-3beta i wzrostu procesu apoptozy.

\section{LOKALIZACJA I FUNKCJE BDNF}

Neurotrofiny są syntetyzowane głównie w ośrodkowym układzie nerwowym, ale również przez nieneuronalne komórki obwodowe takie jak limfocyty $\mathrm{T}$, limfocyty B, monocyty oraz trombocyty [29]. BDNF działa na receptory TrkB lub NT75 w obrębie tkanek, w których został zsyntezowany lub w obrębie tkanek, do których został przetransportowany poprzez krew [25]. Wykazano, że BDNF swobodnie przekracza barierę krew-mózg (BBB) w obydwu kierunkach, a kierunek przepływu zależy od jego gradientu stężeń. [30]. Z badań wynika, że poziom krążącego BDNF we krwi może odzwierciedlać jego poziom w mózgu [31]. Stwierdzono, że poziom BDNF w surowicy ludzi zarówno w spoczynku jak i w trakcie wysiłku fizycznego w $70-80 \%$ jest pochodzenia mózgowego[7,32].

W neuronach BDNF zlokalizowany jest nie tylko w cytosolu, który jest głównym miejscem jego syntezy, ale także w pobliżu kolców dendrytycznych [33,34], przez co może wywierać wpływ na ich rozwój [33,35]. Badania immunochemiczne wykazały, że BDNF jest najobficiej występującą neurotrofiną w mózgu. BDNF zlokalizowano w hipokampie, korze mózgowej, śródmózgowiu, wzgórzu (ciała migdałowate) i podwzgórzu, prążkowiu, moście i rdzeniu przedłużonym [7]. Stwierdzono, że głównym źródłem wydzielania BDNF są dopaminergiczne neurony istoty czarnej i prążkowia [35]. BDNF odgrywa kluczową rolę w rozwoju systemu nerwowego poprzez wpływ na różnicowanie, wzrost neuronów, neurogenezę, modulacje plastyczności oraz neuroregenerację [36].Występowanie BDNF w poszczególnych strukturach mózgu jest związane z modyfikacją ich fizjologicznych funkcji. BDNF wpływa na rozwój neuronów serotoninergicznych, dopaminergicznych, noradrenergicznych i cholinergicznych [37]. Ponadto, uczestniczy w regulacji plastyczności neuronalnej związanej z procesami uczenia się $\mathrm{i}$ pamięci, wpływając na proces długotrwałego wzmocnienia i osłabienia synaptycznego (LTP, ang. Long-term potentiation i LTD, ang. Long-term depression) w hipokampie [38].

\section{ROLA BDNF W PROCESACH NEURODEGENERACJI I NEUROREGENERACJI}

Neurotrofiny poprzez aktywacje szlaku IP3K/Akt kinazy hamują procesy prowadzące do śmierci komórek [5,39]. Stwierdzono, że zmniejszenie ekspresji neurotrofin, a zwłaszcza BDNF obserwowane w procesie starzenia i chorobach neurodegeneracyjnych może przyczyniać się do neurodegeneracji neuronów [40]. Zaobserwowano obniżenie stężenia BDNF we krwi i mózgu u pacjentów z depresją, PD i AD $[37,41]$. Obniżonemu stężeniu BDNF w surowicy i mózgu towarzyszy wzrost neurodegeneracji dopaminergicznych neuronów w PD, co prowadzi do zaburzeń ruchowych, deficytu kognitywnego i zaburzeń mentalnych $[37,41]$, a także koreluje $\mathrm{z}$ zaburzeniem pamięci $\mathrm{w}$ AD $[40,42]$. Istnieją dane wskazujące, że obniżenie poziomu BDNF w PD może przyczyniać się do nadekspresji alfa synukleiny (ASN) oraz zahamowania syntezy dopaminy [43]. BDNF uczestniczy w regulacji hydroksylazy tyrozynowej, która również ulega obniżeniu w PD, w konsekwencji prowadząc do zaburzeń ruchowych $[13,44]$. Wyciszenie genu kodującego BDNF u myszy powodowało utratę neuronów dopaminergicznych, co potwierdza jego protekcyjną rolę $\mathrm{w}$ ochronie neuronów przed ich neurodegeneracją [45]. Istnieją badania, z których wynika, że GDNF również może zapobiegać neurodegeneracji neuronów dopaminergicznych w PD [41]. Neuroprotekcyjne działanie BDNF jest wynikiem aktywacji szlaku TrkB/MAPK/ERK1/2/IP3K/Akt, co wpływa na hamowanie procesu apoptozy, neurotoksyczności glutaminianu i tlenku azotu (NO) oraz na blokowanie uszkodzeń, które wywołuje stres oksydacyjny [19].Warto zaznaczyć, że wzrost stresu oksydacyjnego, neurotoksyczności glutaminianu, produkcji NO i procesu apoptozy obserwuje się w PD [46].

\section{PROTEKCYJNE DZIAŁANIE WYSIŁKU FIZYCZNEGO POPRZEZ REGULACJA POZIOMU BDNF}

Wyniki licznych badań wykazują, że regularna długotrwała aktywność fizyczna zapobiega występowaniu chorób neurodegeneracyjnych u osób starszych. Wysiłek fizyczny powoduje poprawę sprawności ruchowej, zwiększenie siły mięśni u osób w podeszłym wieku. Ponadto, terapia ruchowa $\mathrm{w}$ postaci treningu wytrzymałościowego, treningu oporowego, intensywnego treningu mieszanego lub interwałowego wytrzymałościowego treningu o dużej intensywności (HIIT) powodowała zmniejszenie objawów klinicznych w PD [47]. Długotrwałe treningi wytrzymałościowe i HIIT powodowały zmniejszenie napięcia mięśniowego, sztywności, oraz wpływały korzystnie na równowagę ciała u osób z PD, depresją i AD $[48,49]$. Ponadto, prowadziły do redukcji zaburzeń ruchowych i zmniejszenia deficytu kognitywnego $\mathrm{u}$ pacjentów z PD, co również zostało potwierdzone w badaniach na zwierzętach [44]. Badania młodych mężczyzn dostarczyły dowodów, że jednorazowy aerobowy (tlenowy) wysiłek fizyczny powoduje wzrost poziomu BDNF w osoczu i surowicy [32,50]. Dodatkowo stwierdzono, że kilkutygodniowy lub kilkumiesięczny trening fizyczny powoduje wzrost wyjściowego (spoczynkowego) poziomu BDNF w porównaniu do stanu przed rozpoczęciem treningu [51-53]. Wzrost ten jest uzależniony od intensywności i czasu trwania procesu treningowego[7,54].

Dotychczas uzyskane wyniki badań wskazują, iż wzrost obwodowego BDNF po wysiłkach aerobowych lub siłowych jest efektem przejściowym. W okresie od około 10 do 60 minut po zaprzestaniu wysiłku, poziom obwodowego stężenia BDNF wraca do wartości wyjściowych (przed wysiłkowych), co potwierdzają również nasze badania na osobach niewytrenowanych i wytrenowanych [54]. Co ciekawe, po około 2-3 godz. od chwili zakończenia wysiłku obserwowano znaczący spadek poziomu tej neurotrofiny poniżej wartości wyjściowych [55]. Mechanizm tego zjawi- 
ska próbowali wyjaśnić Knaepen i wsp. [56] sugerując, że wysiłek fizyczny prowadzi do przejściowego zwiększenia syntezy BDNF w komórkach, skąd jego nadmiar może być uwalniany do krwioobiegu, powodując wzrost obwodowego poziomu BDNF. Następnie BDNF może być absorbowany przez tkanki centralne i/lub obwodowe, gdzie może indukować procesy neurotroficzne i neuroprotekcyjne. Ten cykl, przynajmniej częściowo, wyjaśnia szybki powrót stężenia tej neurotrofiny $\mathrm{w}$ okresie restytucji powysiłkowej do wartości obserwowanych przed rozpoczęciem wysiłku lub niższych.

Zwiększoną ekspresję genu kodującego BDNF oraz zwiększony poziom mRNA obserwuje się również w samych mięśniach szkieletowych w odpowiedzi na ich skurcz zarówno u ludzi jak i u laboratoryjnych zwierząt. Sugeruje się jednak, że neurotrofina ta pochodzi z neuronów znajdujących się w obrębie mięśni i nie przechodzi do krwiobiegu. Za taką koncepcją przemawiają dane zaobserwowane zarówno $\mathrm{w}$ badaniach in vivo jak i z wykorzystaniem modelu mięśniowej hodowli komórkowej [54]. Zarówno w badaniu in vivo jak i ex vivo mięśniowy BDNF powodował zwiększenie fosforylacji kinazy białkowej aktywowanej przez AMP (AMPK) oraz karboksylazy acetylo-CoA izoforma $\beta$ (ACC $\beta$ ), co prowadziło do wzrostu utleniania kwasów tłuszczowych [54]. Po 5 dniowym treningu na bieżni również zaobserwowano wzrost ekspresji mRNA BDNF w mięśniu płaszczkowatym myszy, efekt ten jednak nie był widoczny po 10 dniach treningu. Dotychczas nie wykazano, aby w odpowiedzi na wysiłek fizyczny ulegał zmianie poziom mRNA TrkB [57].

Niektórzy badacze sugerują, że krążący we krwi BDNF $\mathrm{w}$ odpowiedzi na wysiłek fizyczny może $\mathrm{w}$ pewnym stopniu odzwierciedlać uwalnianie tej neurotrofiny $\mathrm{z}$ płytek krwi [58]. W badaniu przeprowadzonym na zdrowych mężczyznach wykazano, że w trakcie maksymalnego wysiłku na bieżni $\left(\mathrm{VO}_{2} \max \right)$, poziom BDNF wzrósł zarówno w osoczu, surowicy jak i w płytkach krwi w porównaniu z wartościami spoczynkowymi. Ponieważ nie stwierdzono produkcji BDNF w płytkach krwi, to powyżej opisane zjawisko wskazuje, że w płytkach krwi przechowywany jest krążący BDNF [31]. W swoich badaniach Matthews i wsp. [58] oraz Pratesi i wsp. [59] stwierdzili wzrost ekspresji mRNA BDNF w mięśniach szkieletowych u ludzi po wysiłku fizycznym oraz po stymulacji elektrycznej, ale nie obserwowano uwalniania jego do krwi. Pomimo tego faktu, autorzy odnotowali wzrost poziomu BDNF w surowicy po wysiłku, co jest w zgodzie z obecnie przyjęta koncepcją, która zakłada, że to mózg jest głównym źródłem krążącego we krwi BDNF [7,31]. Z kolei, badając wpływ ośmiotygodniowego treningu aerobowego na poziom BDNF u osób z PD stwierdzono wzrost podstawowego (spoczynkowego) poziomu tej neurotrofiny o ok. $30 \% \mathrm{w}$ surowicy przy braku wzrostu stężenia tej neurotrofiny w płytkach krwi. Tej odpowiedzi towarzyszyło zmniejszenie stanu zapalnego objawiające się obniżeniem stężenia TNF-a i sVCAM-1 w surowicy [60].

Pomimoiżjednorazowy wysiłek powoduje wzrost BDNF we krwi u pacjentów z PD, to jest on krótkotrwały i nie jest skojarzony z poprawą stanu neurologicznego pacjentów z PD. Przeprowadzone badania z wykorzystaniem zwie-

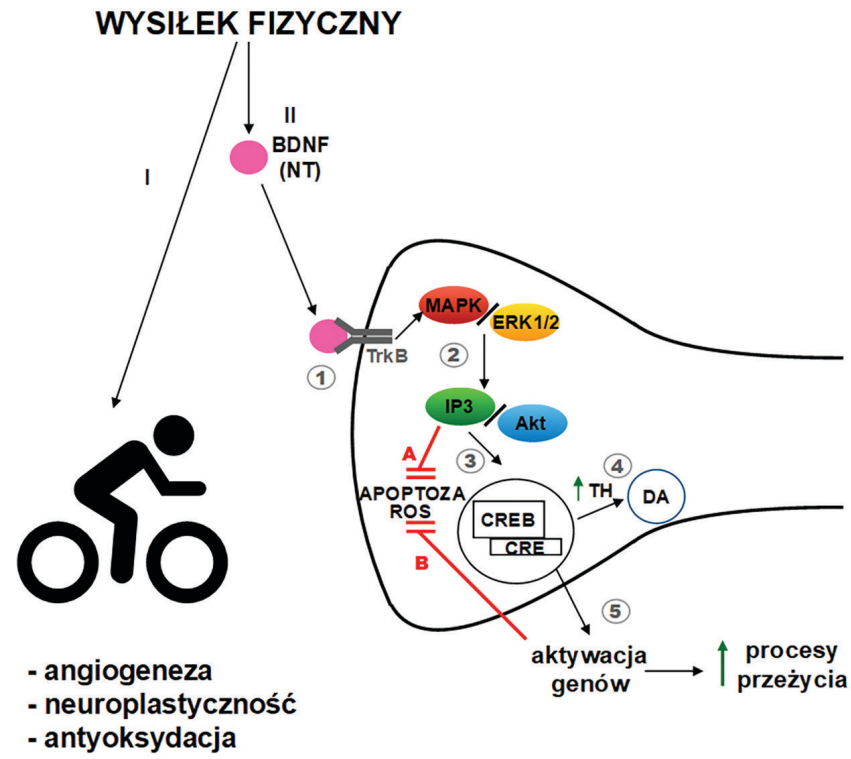

Rycina 1. Odpowiedź organizmu na wysiłek fizyczny: ogólnosystemowa (I) oraz ośrodkowego systemu nerwowego (II). Wysiłek fizyczny powoduje wzrost powinowactwa BDNF do receptora TrkB (1) wywołujac kaskadę wewnatrzkomórkowych sygnałów, między innymi szlakiem MAPK/ERK1/2, z jednej strony hamując apoptozę oraz uwalnianie wolnych rodników - ROS (A), a drugiej prowadzą do fosforylacji czynnika transkrypcyjnego CREB, który łacząc się z elementem CRE w jądrze komórkowym (3) zwiększa transkrypcję genu hydroksylazy tyrozynowej (4) odpowiedzialnej za konwersję Tyrozyny do L-DOPA, z której powstaje dopamina (4) oraz przeżyciu neuronów (5) tym samym blokując apoptozę i hamując powstawanie ROS (B). Rycinę opracowano na podstawie prac [62-65].

rzęcego modelu parkinsonizmu dostarczyły dowodów, że dopiero powtarzanie przez kilka tygodni jednorazowych wysiłków fizycznych o średniej bądź dużej intensywności lub proces treningowy wywołują wzrost poziomu BDNF i receptora TrkB w regionach mózgu odpowiedzialnych za aktywność motoryczną u szczurów [36,61]. Pod wpływem procesu treningowego obserwowano zwiększoną ekspresję BDNF w hipokampie, korze mózgowej, prążkowi, pniu mózgu i rdzeniu kręgowym [61]. Badania na zwierzętach pokazały, że długotrwały 6-tygodniowy trening wytrzymałościowy powodował wzrost ekspresji zarówno receptora TrkB jak i ekspresję mRNA hydroksylazy tyrozynowej (TH) w strukturach współuczestniczących w pozapiramidowej regulacji ruchu, tj. w prążkowiu i śódmózgowiu [61-63]. Jak wcześniej wspomniano, kluczowym elementem neuroprotekcji związanej z neurotrofinami jest szlak IP3K/Akt [23]. Przedstawiono także dane, które wskazują, że aktywność fizyczna może działać neuroprotekcyjnie poprzez aktywacje szlaku PGC1 $\alpha$ /FNDC5/BDNF/ ERK1/2 [64,65]. Ponadto, pod wpływem wysiłku dochodzi do wzrostu transkrypcji PGC1a, białka regulującego biogenezę mitochondrialną, który $\mathrm{w}$ kompleksie z ERRa może pobudzać ekspresję proteiny FNDC5 w mózgu. Po rozczepieniu peptydu sygnałowego i miejsca cięcia flankującego domenę fibronektyny, wytwarza się glikopeptyd irysynowy, który wyzwala ekspresję BDNF [66-68]. BDNF łączy się z receptorem TrkB na powierzchni jednostki nerwowo-naczyniowej, wywołując uruchomienie kaskady wewnątrzkomórkowych sygnałów, włączając w to przede 
wszystkim, aktywowaną mitogenami kinazę białkową MAPK/ERK1,2 i zależną od wapnia i kalmoduliny kinazę białkową (CaM-K), które są odpowiedzialne za fosforylację CREB (czynnika transkrypcyjnego, kluczowego dla długoterminowej plastyczności neuronalnej), który kolejno łączy się $\mathrm{z}$ odpowiednia sekwencją $\mathrm{w}$ genie TH tym samym zwiększając transkrypcję genu TH. Dochodzi do zwiększenia aktywności enzymu TH, który bierze udział w konwersji L-tyrozyny do L-DOPA, z której powstaje dopamina, sprzyjając w uzyskanych stężeniach przeżyciu neuronów dopaminergicznych (Ryc. 1) [62,68,69]. Warto jednak zaznaczyć, że zbyt duże stężenie dopaminy może prowadzić do aktywacji procesów neurodegeneracyjnych i śmierci neuronów [62].

Cześć autorów sugeruje współudział wysiłku fizycznego w inicjacji ekspresji genu kodującego BDNF poprzez aktywację monoaminergiczną (Ach i/lub GABA), zwiększając neurotransmisję adrenergiczną (NA) lub serotoninergiczną (5-HT) na podstawie faktu, że długotrwała aktywność fizyczna powoduje wzrost aktywacji NA i 5-HT (odpowiedzialnych za regulację plastyczności synaps) i działa protekcyjnie na mózg [62]. Dodatkowo twierdzi się, że treningi fizyczne mają działanie podobne do leków antydepresyjnych i poprawiają leczenie zarówno krótko jak i długotrwałej depresji [63]. Sugeruje się także, że aktywacja receptorów $\beta$-adrenergicznych przez NA może być niezbędna do regulacji BDNF wywołanej wysiłkiem fizycznym. Jako wewnątrzkomórkowy szlak sygnałowy ekspresji genu kodującego BDNF aktywowany przez NA wskazuje się drogę GPCR-MAPK-IP ${ }_{3} \mathrm{~K}[63,64]$. Warto podkreślić, że badania prowadzone na pacjentach z depresją nie wykazują związku pomiędzy ćwiczeniami aerobowymi a poziomem BDNF [64]. U pacjentów z depresją leczonych farmakologicznie $\mathrm{z}$ równoczesną terapią ruchową (zwiększona aktywność fizyczna) nie obserwowano wzrostu poziomu BDNF $\mathrm{w}$ surowicy $\mathrm{w}$ porównaniu do osób tylko leczonych farmakologicznie [65], co wskazuje na potrzebę prowadzenia dalszych badań wyjaśniających ewentualny wpływ aktywacji Ach i/lub GABA na regulację ekspresji genu kodującego BDNF.

Udowodniono, że wysiłek fizyczny ma wpływ na pamięć, nastrój, plastyczność oraz zdolność uczenia się [58]. Efekt wzmożonej aktywności fizycznej najwyraźniej widoczny jest w zakręcie zębatym oraz hipokampie, czyli strukturach mózgu odpowiedzialnych za pamięć i proces uczenia się. $\mathrm{W}$ badaniach na myszach obserwuje się $\mathrm{w}$ tych strukturach m.in. większy przepływ krwi, a także ważne zmiany neurologiczne w ich obrębie, takie jak zwiększoną plastyczność oraz neurogenezę. Istnieją także dane, które wskazują, że BDNF uczestniczy w regulacji metabolizmu neuronów, ich rozwoju i prawidłowego działania przy współudziale insulinopodobnego czynnika wzrostu-1 (IGF-1) [68]. Niektórzy autorzy wskazują, że obecność IGF-1 oraz BDNF są wymagane dla żywotności i funkcji komórek neuronalnych [69] . Wiadomo, że wysiłek fizyczny zwiększa wydzielanie IGF-I oraz VEGF (naczyniowo śródbłonkowego czynnika wzrostu) i wspólnie z BDNF może poprawiać pamięć poprzez zmiany plastyczności synaptycznej, ilości synaps i neurotransmisji w dojrzałych neuronach [70].

\section{PODSUMOWANIE}

Wzmożona aktywność fizyczna inicjuje wydzielanie wielu neurotrofin, $w$ tym BDNF. W przypadku BDNF powoduje ona wzrost wyjściowego (spoczynkowego) poziomu tej neurotrofiny. Zjawisko to szczególnie wyraźne występuję $\mathrm{w}$ odpowiedzi na proces treningowy, zarówno $\mathrm{w}$ treningu wytrzymałościowym (duża objętość - czas trwania jednorazowych wysiłków) jak i w treningu interwałowym (duża intensywność jednorazowych wysiłków). Wzrost spoczynkowego poziomu BDNF skojarzony jest ze zmniejszeniem napięcia mięśniowego i sztywności mięśni szkieletowych, co prowadzi do redukcji zaburzeń ruchowych oraz zmniejszenia deficytu kognitywnego u pacjentów z PD. Dane te również zostały potwierdzone $\mathrm{z}$ wykorzystanie modeli zwierzęcych parkinsonizmu. Ponadto, badania z wykorzystaniem modeli zwierzęcych dostarczyły pierwszych dowodów, że długotrwały trening wytrzymałościowy może powodować wzrost ekspresji zarówno receptora TrkB jak i ekspresję mRNA hydroksylazy tyrozynowej (TH) w strukturach współuczestniczących $\mathrm{w}$ pozapiramidowej regulacji ruchu, tj. w prążkowiu i śródmózgowiu. BDNF łącząc się $\mathrm{z}$ receptorem TrkB na powierzchni jednostki nerwowo-naczyniowej, wywołuje uruchomienie kaskady wewnątrzkomórkowych sygnałów aktywowanych mitogenami kinazę białkową MAPK/ERK1,2 i zależną od wapnia i kalmoduliny kinazę białkową (CaM-K), które są odpowiedzialne za fosforylację CREB (czynnika transkrypcyjnego, kluczowego dla długoterminowej plastyczności neuronalnej), który kolejno łączy się z odpowiednia sekwencją w genie TH zwiększając transkrypcję genu TH co prowadzi do zwiększenia konwersji L-tyrozyny do L-DOPA, powstania dopaminy oraz blokując proces apoptozy, sprzyjąc przeżyciu neuronów dopaminergicznych.

\section{PIŚMIENNICTWO}

1. Barde YA, Edgar D, Thoenen H (1982) Purification of a new neurotrophic factor from mammalian brain. EMBO J 1: 549-553

2. Hohn A, Leibrock J, Bailey K, Barde YA (1990) Identification and characterization of a novel member of the nerve growth factor/brain-derived neurotrophic factor family. Nature 344: 339-341

3. Zhang HT, Li LY, Zou XL, Song XB, Hu YL i in. (2007) Immunohistochemical Distribution of NGF, BDNF, NT-3, and NT-4 in adult rhesus monkey brains. J Histochem Cytochem 55: 1-19

4. Mowla SJ, Farhadi HF, Pareek S, Atwal JK, Morris SJ, Seidah NG, Murphy RA (2001) Biosynthesis and post-translational processing of the precursor to brain-derived neurotrophic factor. J Biol Chem 276: 12660-12666

5. Zoladz JA, Pilc A (2010) The effect of physical activity on the brain derived neurotrophic factor: from animal to human studies. J Physiol Pharmacol 61: 533-541

6. Aid T, Kazantseva A, Piirsoo M, Palm K, Timmusk T (2007) Mouse and rat BDNF gene structure and expression revisited. J Neurosci Res 85: 525-535

7. Cunha C, Brambilla R, Thomas KL (2010) A simple role for BDNF in learning and memory? Front Mol Neurosci 3: 1-14

8. Singh A, Sen D (2017) MicroRNAs in Parkinson's disease. Exp Brain Res 235: 2359- 374

9. Mercader JM, Fernández-Aranda F, Gratacòs M, Ribasés M, Badía A Villarejo C, Solano R, González JR, Vallejo J, Estivill X (2009) Blood levels of brain-derived neurotrophic factor correlate with several psychopathological symptoms in anorexia nervosa patients. Neuropsychobiology 56: 185-90 
10. Majidinia M, Mihanfar A, Rahbarghazi R, Nourazarian A, Bagca BG, Avci CB (2016) The role of non-coding RNAs in Parkinson's disease Mol Biol Rep 43: 1193-1204

11. Egan MF, Kojima M, Callicott JH, Goldberg TE, Kolchana BS, Bertolino A, Zaitsev E, Gold B, Goldman D, Deann M, Lu B, Weinberger DR (2003) The BDNF val66met polymorphism affects activity-dependent secretion of BDNF and human memory and hippocampal function. Cell 112: 257-269

12. Mellios N, Huang H-S, Grigorenko A, Rogaev E, Akbraian S (2008) A set of differentially expressed miRNAs, including miR-30a-5p, act as post-transcriptional inhibitors of BDNF in prefrontal cortex Hum Mol Genetics 17: 3030-3042

13. Gao L, DDiaz-Corrales FJ, Carrillo F, Diaz-Martin J, Caceres-Redondo MT, Carballo M, Palomino A, Lopez-Barneo J, Mir P (2010)Brain-derived neurotrophic factor G196A polymorphism and clinical features in Parkinson's disease. Acta Neurol Scand 122: 41-45

14. Chen A, Xiong LJ, Tong Y, Mao M (2013) Neuroprotective effect of brain-derived neurotrophic factor mediated by autophagy through the PI3K/Akt/mTOR pathway. Mol Med Rep 8: 1011-1016

15. Fayard B, Loeffler S, Weis J, Vogelin E, Kruttgen A (2005) The secreted brain-derived neurotrophic factor precursor pro-BDNF binds to TrkB and p75NTR but not to TrkA or TrkC. J Neurosci Res 80: 18-28

16. Kaplan DR, Miller FD (2000) Neurotrophin signal transduction in the nervous system. CurrOpinNeurobiol 10: 381-391

17. Roux PP, Barker PA (2002) Neurotrophin signaling through the p75 neurotrophin receptor. Prog Neurobiol 67: 203-233

18. Nykjaer A, Lee R, Teng KK, Jansen P, Madsen P, Nielsen MS, Jacobsen C, Kliemannel M, Schwarz E, Willnow TE, Hempstead BL, Petersen CM (2004) Sortilin is essential for proNGF-induced neuronal cell death. Nature 427: 843-848

19. Numakawa T, Suzuki S, Kumamaru E, Adachi N, Richards M, Kunugi $\mathrm{H}$ (2010) BDNF function and intracellular signaling in neurons. Histol Histopathol 25: 237-258

20. Chen MJ, Russo-Neustadt AA (2005) Exercise activates the phosphatidylinositol 3-kinase pathway. Brain Res Mol Brain Res 135: 181-193

21. Pizzorusso T, Ratto GM, Putignano E, Maffei L (2000) Brain-derived neurotrophic factor causes cAMP response element-binding protein phosphorylation in absence of calcium increases in slices and cultured neurons from rat visual cortex. J Neurosci 20: 2809-2816

22. Bourque M, Dluzen D, Paolo T (2012) Signaling pathways mediating the neuroprotective effects of sex steroids and SERMs in Parkinson's disease. Front Neuroendocrinol 33: 169-178

23. Chan TO, Rittenhouse SE, Tsichlis PN (1999) AKT/PKB and other D3 phosphoinositide-regulated kinases: kinase activation by phosphoinositide-dependent phosphorylation. Annu Rev Biochem 68: 965-1014

24. Lommatzsch M, Zingler D, Schuhbaeck K, Schloetcke K, Zingler C, Schuff-Werner P, Virchow JC (2005) The impact of age, weight and gender on BDNF levels in human platelets and plasma. Neurobiol Aging 26: 115-123

25. Pan W, Banks WA, Fasold MB, Bluth J, Kastin AJ (1998) Transport of brain-derived neurotrophic factor across the blood-brain barrier. Neuropharmacology 37: 1553-1561

26. Sartorius A, Hellweg R, Litzke J, Vogt M, Dormann C, Vollmayr B, nker-Hopfe H, Gass P (2009) Correlations and discrepancies between serum and brain tissue levels of neurotrophins after electroconvulsive treatment in rats. Pharmacopsychiatry 42: 270-276

27. Cho HC, Kim J, Kim S, Son YH, Lee N, Jung SH (2012) The concentrations of serum, plasma and platelet BDNF are all increased by treadmill VO-max performance in healthy college men. Neurosci Lett 519: $78-83$

28. Tongiorgi E, Righi M, Cattaneo A (1997) Activity-dependent dendritic targeting of BDNF and TrkB mRNAs in hippocampal neurons. J Neurosci 17: 9492-9505

29. Tongiorgi E (2008) Activity-dependent expression of brain-derived neurotrophic factor in dendrites: facts and open questions. Neurosci Res 61: 335-346
30. Hyman C, Juhasz M, Jackson C, Wright P, Ip NY, Lindsay RM (1994) Overlapping and distinct actions of the neurotrophins BDNF, NT-3, and NT-4/5 on cultured dopaminergic and GABAergic neurons of the ventral mesencephalon. J Neurosci 14: 335-347

31. Klintsova AY, Dickson E, Yoshida R, Greenough WT (2004) Altered expression of BDNF and its high-affinity receptor TrkB in response to complex motor learning and moderate exercise. Brain Res 1028: 92-104

32. Filus JF, Rybakowski J (2010) Serum BDNF levels and intensity of depressive symptoms. Neuropsychiatriai Neuropsychologia 5: 155-162

33. Zheng F, Zhou X, Moon C, Wang H (2012) Regulation of brain-derived neurotrophic factor expression in neurons. Int J Physiol Pathophysiol Pharmacol 4: 188-200

34. Zheng WH, Quirion R (2004) Comparative signaling pathways of insulin-like growth factor-1 and brain-derived neurotrophic factor in hippocampal neurons and the role of the PI3 kinase pathway in cell survival. J Neurochem 89: 844-852

35. Ventriglia M, Zanardini CB, Zanetti O, Volpe D, Pasqualetti $\mathrm{P}$, Gennarelli M, Bocchio-Chiavetto L (2013) Serum brain-derived neurotrophic factor levels in different neurological diseases. BioMed Res. Int 2013, ID 901082, 1-7

36. Howells DW, Porritt MJ, Wong JY, Batchelor PE, Kalnins R, Hughes AJ, Donnan GA (2000) Reduced BDNF mRNA expression in the Parkinson's disease substantia nigra. Exp Neurol 166:127-135

37. Scalzo P, Kummer A, Bretas TL, Cardoso F, Teixeira AL (2010) Serum levels of brain-derived neurotrophic factor correlate with motor impairment in Parkinson's disease. J Neurol 257: 540-545

38. Yuan TF, Li J, Shan CL (2014) The epigenetics changes in Parkinson's Disease: a novel therapeutic target. CNS Neurosci Ther 20: 299-300

39. Langfort J, Chalimoniuk M, Kania D, Lukacova N, Chrapusta SJ, Endurance training counteracts MPTP treatment-related changes in midbrain contents of dopamine and dopamine metabolites, and in parvalbumin expression., XX World Conngress on Parkinson's Disease and Related Disorders, Geneva, Switzerland December, 8-11, 2013

40. Porritt MJ, Batchelor PE, Howells DW (2005) Inhibiting BDNF expression by antisense oligonucleotide infusion causes loss of nigral dopaminergic neurons. EXP Neurol 192: 226-234

41. Uhrbrand A, Stenager E, Pedersen MS, Daglas U (2015) Parkinson's disease and intensive exercise therapy-a systematic review and meta-analysis of randomized controlled trials. J Neurol Sci 353: 9-19

42. Marusiak J, Żeligowska E, Mencel J i in. (2015) Interval training-induced alleviation of rigidity and hipertonia In patients with Parkinson's Disease is accompanied by increased basal serum brain-derived neurotrophic factor. J Rehabil Med 47: 372-375

43. Angelucciiwsp. 2015Angelucci F, Caltagirone C, Costa A(2015) Cognitive training in neurodegenerative diseases: a way to boost neuroprotective molecules? Neural Regen Res 10: 1754-1755

44. Skriver K, Roig M, Lundbye-Jensen J i in. (2014) Acute exercise improves motor memory: exploring potential biomarkers.Neurobiol Learn Mem 116: 46-58

45. Zoladz JA, Pilc A, Majerczak J i in. (2008) Endurance training increases plasma brain-derived neurotrophic factor concentration in young healthy men.J Physiol Pharmacol 59: 119-132

46. Sutoo D, Akiyama K (2003) Regulation of brain function by exercise. Neurobiol Dis 13: 1-14

47. Seifert T, Brassard P, Wissenberg M (2010) Endurance training enhances BDNF release from the human brain.Am J PhysiolRegullntegrCompPhysiol 298: R372-R377

48. Pedersen BK, Pedersen M, Karen Si in. (2009) Role of exercise-induced brain-derived neurotrophic factor production in the regulation of energy homeostasis in mammals. Exp Physiol 94: 1153-1160

49. Szuhany KL, Bugatti M, Otto MW (2015) A meta-analytic review of the effects of exercise on brain-derived neurotrophic factor. J Psychiatr Res 60: 56-64

50. Piotrowicz Z, Czuba M, Langfort J, Chalimoniuk M(2017) Alterations in serum BDNF and catecholamines during exercise to volitional exhaustion - the influence of normobaric hypoxia and endurance training. Folia Neuropathol 55: 173-173 
51. Knaepen K, Goekint M, Heyman EM, Meeusen R. Neuroplasticity (2010) Exercise-Induced Response of Peripheral Brain-Derived Neurotrophic Factor. A Systematic Review of Experimental Studies in Human Subjects. Spons Med 40: 766-801

52. Sakuma K, Yamaguchi A (2011) The recent understanding of the neurotrophin's role in skeletal muscle adaptation. J Biomed Biotechnol 2011: 201696

53. Ahlskog JE (2011) Does vigorous exercise have a neuroprotective effect in Parkinson disease? Neurology 77: 288-294

54. Liu P, Nusslock R (2018) Exercise-Mediated Neurogenesis in the Hippocampus via BDNF. Front Neurosci12: 52-52

55. Zoladz JA, Majerczak J, Zeligowska E, Mencel J, Jaskolski A, Jaskolska A, Marusiak J (2014) Moderate-intensity interval training increases serum brain-derived neurotrophic factor level and decreases inflammation In parkinson's disease patients. J Physiol Pharmacol 65: 441-448

56. Chalimoniuk M, Chrapusta SJ, Lukacova N, Langfort J (2015) Endurance training upregulates the nitric oxide/soluble guanylyl cyclase/ cyclic guanosine 3',5'-monophosphate pathway in the striatum, midbrain and cerebellum of male rats. Brain Res 1618: 29-40

57. Real C, Ferreira A, Chaves-Kristen G, Torrao A, Pires R, Britto L (2013) Neuroscience 237: 118-129

58. Matthews VB, Aström MB, Chan MH, Bruce CR, Krabbe KS, Prelovsek O, Akerström T, Yfanti C, Broholm C, Mortensen OH, Penkowa M, Hojman P, Zankari A, Watt MJ, Bruunsgaard H, Pedersen BK, Febbraio MA (2009) Brain-derived neurotrophic factor is produced by skeletal muscle cells in response to contraction and enhances fat oxidation via activation of AMP-activated protein kinase. Diabetologia 52: $1409-1418$

59. Pratesi A, Tarantini F, Di Bari M (2013) Skeletal muscle: an endocrine organ. Clin Cases Miner Bone Metab 10: 11-14

60. Pareja-Galeano H, Mayero S, Perales M, Garatachea N, Santos-Lozano A, Fiuza-Luces C, Emanuele E, Gálvez BG, Sanchis-Gomar F, Lucia A (2016) Biological Rationale for Regular Physical Exercise as an Effective Intervention for the Prevention and Treatment of Depressive Disorders. Curr Pharm Des 22: 3764-3775

61. Farshbaf MJ, Ghaedi K, Megraw TL, Crtiss J, Faradonbeh MS, Vaziri P, Nasr-Esfahani MH (2015) DoesPGC1a/FNDC5/BDNF Elicit the Ben- eficial Effects of exercise on Neurodegenerative Disorders? Neuromol Med DOI 10.1007/s12017-015-8370

62. WrannCh, White J, Salogiannnis J, Laznik-Bogoslavski DL, Wu J, Ma D, Lin JD, Greenberg M, Spiegelman B (2013) Exercise Iduces Hippocampal BDNF through a PGC-1a/FNDC5 Pathway. Cell Metab 18: 649-659

63. Gomez-Pinilla F, Hillman Ch (2013) The influence of exercise on cognitive abilities. Compr Physiol 3: 403-428

64. McMorris T (2016) Developing the cateholamines hypothesis for acute exercise-cognition in humans: Lessons from animal studies. Physiol Behav 165: 291-299

65. DaSilva PG, Domingues DD, de Carvalho LA, Allodi S, Correa CL (2016) Neurotrophic factors in Parkinson's disease are regulated by exercise: Evidence-based practice. J Neurol Sci 363: 5-15

66. MA Q (2008) Beneficial effects of moderate voluntary physical exercise and its biological mechanisms on brain health. Neurosci Bull 24: 265-270

67. Lamego MK, de Souza Moura AM, Paes F, Ferreira Rocha NB, de SáFilho AS, Lattari E, Rimes R, Manochio J, Budde H, Wegner M, Mura G, Arias-Carrión O, Yuan TF, Nardi AE, Machado S (2015) Aerobic exercise does not predict brain derived neurotrophic factor and cortisol alterations in depressed patients. CNS Neurol Disord Drug Targets 14: $1116-1128$

68. Schuch FB, Vasconcelos-Moreno MP, Borowsky C, Zimmermann AB, Wollenhaupt-Aguiar B, Ferrari P, de Almeida Fleck MP (2014) The effects of exercise on oxidative stress (TBARS) and BDNF in severely depressed inpatients. Eur Arch Psychiatry Clin Neurosci 264: 605-613

69. Zheng WH, Quirion R (2004) Comparative signaling pathways of insulin-like growth factor-1 and brain-derived neurotrophic factor in hippocampal neurons and the role of the PI3 kinase pathway in cell survival. J Neurochem 89: 844-852

70. Maass A, Düzel S, Brigadski T, Goerke M, Becke A, Sobieray U, Neumann K, Lövdén M, Lindenberger U, Bäckman L, Braun-DullaeusR,Ahrens D, Heinze HI, Müller NG, Lessmann V, Sendtner M, Düzel E (2016) Relationships of peripheral IGF-1, VEGF and BDNF levels to exercise-related changes in memory, hippocampal perfusion and volumes in older adults. Neuroimage 131: 142-154

\title{
The role of the brain-derived neurotrophic factor (BDNF) in neurodegenerative processes and in the neuroregeneration mechanisms induced by increased physical activity
}

\section{Paulina Małczyńska ${ }^{1}$, Zofia Piotrowicz ${ }^{2}$, Dorota Drabarek ${ }^{3}$, Józef Langfort ${ }^{4}$, Małgorzata Chalimoniuk ${ }^{3, \bigotimes}$}

${ }^{1}$ Department of Genetics, Institute of Psychiatric and Neurology, 9 Sobieskiego St., 02-957 Warsaw, Poland

${ }^{2}$ Department of Sports Theory, The Jerzy Kukuczka Academy of Physical Education, 72A Mikołowska St., 40-065 Katowice, Poland

${ }^{3}$ Department of Tourism and Health in BiałaPodlaska, Józef Pilsudski University of Physical Education in Warsaw, 2 Akademicka St. 21-500

Biała Podlaska, Poland

${ }^{4}$ Department of Experimental Pharmacology, Mossakowski Medical Research Center Polish Academy of Science, 5 Pawińskiego St., $02-106$ Warsaw, Poland

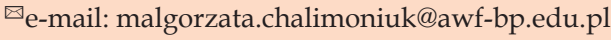

Key words: BDNF, neurodegeneration, neuroregeneration, physical activity, training

\begin{abstract}
The brain-derived neurotrophic factor (BDNF) belongs to the family of neurotrophins synthesized in the central and peripheral nervous system. Several specific miRNAs (miR-1, miR-126 and miR-30a-5p) are involved in the regulation of BDNF synthesis. Its synthesis is also influenced by the SNP-Val 66Met BDNF polymorphism (rs 6265). BNDF can cross the blood brain barrier. Its role in the central and peripheral rely on regulation of important physiological functions, i.e. development and growth of neurons, the process of learning and memory, apoptosis, neurogenesis and neuroregenation through activation of TRkB and p75NTR receptors. Lowering BDNF level mediates neurodenegeration of neurons including dopaminergic neurons in Parkinson's disease. Regular long-term repeated physical exercise and/or moderate to high intensity training induces an increase level of BDNF and TrkB receptors in the brain regions responsible for motor activity, preventing neurodegeneration, especially in the elderly people. Lowering BDNF level mediates in neurodenegeration of neurons including dopaminergic neurons in Parkinson's disease.
\end{abstract}

